\title{
一特 集
}

教育と言語

\section{複言語主義に向けた EU の言語教育政策}

園山 大祐

(大分大学)

\section{はじめに}

EU (European Union) は1951 年に、ベルギー、フランス、西ドイツ、イタリア、 ルクセンブルク、オランダの6カ国で調印され、1952年に発効した「欧州石炭鉄 鋼共同体 (ECSC)」に始まる。今年は、1957年3月25日に調印された「欧州経済 共同体 (EEC) 条約」と「欧州原子力共同体 (EURATOM) 条約」から50年という 記念の年「1957年から一緒（Together Since 1957)」である。さらに、2007年1月 1 日には、ブルガリアとルーマニアが新規に加盟して、4 億 9 千万人の経済圈と なった。

今日のヨーロッパは、EUという地域統合と同時に、文化の多様性を尊重する という2つの社会問題を抱えている。近年新たに加盟した国は、人口的には大国 とは言えないが、民族、言語的には多様な国である。「ヨーロッパ人」をひとく くりに定義することはますます難しくなっている。ヨーロッパ統合とは、こうし た多様な文化圈を経済以外の政治、社会、教育における調整をも意味する。この 文化の多様性を象徴していることの1つに言語がある。ここでは、ヨーロッパと いう地域を EU (European Union) 加盟国27 力国に限定して、言語の多様性を尊重 した教育政策について考察する。

本稿では、言語の多様性をキーワードに、様々な条約を通じて言語の多様性が 尊重されていることを確認した上で、その言語政策と教育状況の進展について述 べる。なかでも、複数 (母語以外に2つ) の言語を習得するための施策について 注目する。なお、公用語以外の、国内（域内）における民族的マイノリティの言 語 (地域語、少数言語、移民子弟の母語など) にも適宜触れることにしたい。 


\section{EUの「多様性の中の統一」を象徴する言語政策}

ヨーロッパの多言語主義の由来は、EUの創立国の1つであるルクセンブルク やベルギーのような一国家に複数の公用語が認められた国があるためである。ち なみに、新規に加盟したブルガリアとルーマニアを含めると EUの公用語として 認められている数は23に上る ${ }^{(1)}$ 。この公用語が、EU予算においても重要な意味 を持つことは言うまでもない (2)。国際的な会議において、各発言をすべての公用 語に訳す責任を果たすためには、506方向の通訳が必要となるという。こうした 財政的負担を犠牲にしても、「多様性の中の統一 (Unité dans la diversité)」という スローガンのもと、言語の多様性 (Diversités linguistiques) あるいは多言語主義 (multilinguisme) は、異質なものが混在しているるつぼ (creuset) ではなく、こ れら母語の多さは豊かさの源であり、相互理解とより偉大な連帯に向けた道しる べとして多様性をたたえる共同住宅として重視される(3)。

このことが、よりはっきりと明記されたのは、「EU基本権憲章」(4) (2000年 12 月) である。第22条では、言語、宗教、文化の多様性への尊重が詔われ、その 21 条 では、いかなる差別も許されないとしている 151 条の文化に関する条文である ${ }^{(6)}$ 。

この憲章の精神は、2001 年の「欧州言語年2001」による一般市民への啓蒙活動 として引き継がれ(7)、2002年3月のバルセロナ欧州理事会 (European Council) で 欧州委員会 (European Commission) に提案され、1995年以降教育白書で言及さ れた「少なくとも母語以外に2つの外国語の学習の機会を保障する」ことが具体 的な教育目標とされた ${ }^{(8)}$ 。また、この 2002 年 2 月 14 日付け ${ }^{(9)}$ の教育閣僚理事会に おいてヨーロッパの教育制度の目標達成のモニタリングを行うことを決定し、基 礎能力の $1 つ に$ 外国語 $^{(10)}$ の能力が組み込まれたことが、より言語教育の政策を加 速化させていくことになった。そして2003年7月24日の採択に結びついていっ た (「外国語の学習と言語の多样性の促進計画：2004-2006年行動計画」) (11) 。 うした目標は、2000年のリスボンで行われた欧州理事会において決められ、「リ スボン戦略」と呼ばれている。この「リスボン戦略」のもと、「教育と訓練2010」 (Education \& Training 2010) という2010年に向けた教育の到達目標が先のバルセ ロナ欧州理事会で数値目標として示され、そのなかで言語教育に関する指標も定 
められることになった (12) 。ただ、言語教育に関する充分な指標が存在しないこと から、その改定が余儀なくされ、2005年5月24日の決議に新指標が作成された ${ }^{(3)}$ 。 新指標では、外国語を学習している前期・後期中等教育の生徒分布と、後期中等 教育で生徒 1 人が学習した外国語の平均数を示すこととなった。

ただ、こうした政策以前から、欧州評議会 (Council of Europe) において、 1954 年 12 月に欧州文化条約 (European Cultural Conventions) が調印され、文化・

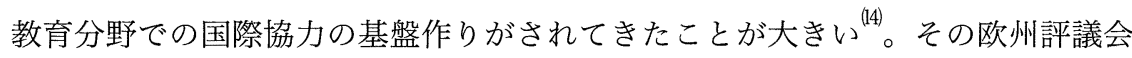
が言語について初めて具体的な活動を示したのは、1961年、ハンブルクで開催 された教育閣僚理事会の現代語教育の推進に関する決議である ${ }^{(5)}$ 。これ以後、欧 州評議会は、言語教育政策の目的として、以下の5つを揭げている

・複言語主義の促進：すべての人は、いくつかの言語でコミュニケーションす る能力を生涯にわたり、必要に応じて向上させる権利がある。

・言語の多様性の促進：ヨーロッパは多言語社会であり、すべての言語はコミュ ニケーションやアイデンティティの表現方式として等しく重要である。すべ ての人は自分の言語を学ぶ権利がある。

・相互理解の促進:ほかの言語を学ぶことは、文化の違いを認め、異文化コミュ ニケーションを促進するための重要な条件である。

・民主的市民の推進 : 多言語社会での個人の民主的、社会的プロセスへの参加 は、それぞれが複言語能力を持つことにより実現することができる。

-社会的結束の促進 : 個人の成長や教育、雇用、情報へのアクセス、文化的向 上における機会の均等は、生涯を通した言語学習によるところが大きい。

欧州評議会は、また、上述した「欧州言語年2001」をEUとの協力で開催して いる。こうした言語教育へのこだわりは、1971年にスイスのルシュリコンで行 われた「成人教育における言語についてのシンポジウム」に始まるとされている。 このシンポジウムは、言語学習・教育のプロセスそのものを民主化するという言 語教育の新しい原則を打ち出した。その後、学習目標を特定するための機能一概 念モデルを開発し、文化協力、外国での日常生活においてその国の人々と交流す るために必要な最低限の能力を Thresholdレベル（注(16)参照）と規定、その内容 を言語材料と言語機能・概念の面から具体的に示した。その 20 年後の 1991 年に、 
同じルシュリコンで欧州評議会とスイス連邦政府によるシンポジウムが開催さ れ、次のような一致がみられた。第 1 に相互理解のための言語学習・教育が重要 である。第2に、言語学習は就学前児童から成人まで、生涯を通して行われるべ きである。第 3 に、全レベルのヨーロッパ共通フレームワークの開発が望ましい （吉島・大橋 (2004)、Conseil de l'Europe (2000) p.11)。

このシンポジウムを受けて、「言語のための欧州共通参照枠 (CEF: Common European Framework of Reference for Language)」と「欧州言語ポートフォリオ(ELP: European Language Portfolio)」が開発され、今日一部の加盟国において外国語の 学習指導要領や高等教育における言語能力基準として活用されている ${ }^{(17)}$ 。また、 近年では、外国語教育という観点から、「外国語以外の教科を外国語で教える教 授法 (CLIL: Content Based Language Learning, Content-and-Language-IntegratedLearning)」の開発が進められている。こうしたことが、EUにおいても1995年か ら推奨され、Eurydiceではその調査報告書 (EMILE: L'enseignement d'une matière intégré à une langue étrangère) も2006年に提出されている(18)。こうした言語教育 の内容、方法、評価などは、各国の教育政策にも影響を与えていることは確かで ある(19)。

また、こうした CEFの枠組みの策定の意味は、次の点でより重要と考えられ る。EUは多言語主義を基調としてきたため、母語以外に2つの外国語の習得を 目標に掲げるに当たって、その2つの外国語の能力を、母国語（母語）と同様の 能力を求めるような多言語主義から、複言語主義を基準にする点を導入するきっ かけとなったからである。つまり、欧州評議会の言うところの、すべての外国語 (たとえば、第1 と第2外国語)を同じレベルでマスターするということではなく、 第1外国語は「国際コミュニケーションの道具」として、第2外国語は「異文化間 交流や異文化理解を目標に特定の地域・文化と密接に関連する学習」を可能にす る言語として学び、第 3 外国語は職業上必要な目的に応じて学習」するなど、到 達度や運用領域に相違をおくことを前提に、複数の外国語の運用能力の習得を目

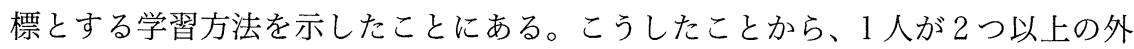
国語を学習することで、グローバル化する社会で一外国語(英語)への集中を避け、 社会全体として使用可能な言語が多様化するねらいがある(杉谷ほか)。これは、 複言語主義と呼ばれている。2002-3 年度のEMILEの調査結果をみると、キプロ 
ス、デンマーク、ギリシャ、ポルトガル以外のすべての加盟国では、その実践が 導入されている(20)

\section{2. 外国語教育の現状}

$\mathrm{EU}$ は定期的に市民の意識調査を行っている。そのユーロバロメーター調査に、 2005 年 11 月から 12 月に 28,694 人の 15 歳以上の EU加盟国出身者に言語につい てインタビューを行ったものがある(21)。この調査によると、56\%が 1 つ上の外 国語を話し (2001 年時点と比較すると $9 \%$ 上昇)、 $28 \%$ が2つ以上を、3つ以上は $11 \%$ て他方 $44 \%$ が1つも話すことができないと回答している。最も話せる外 国語は、英語で $38 \%$ と最も高く、ついで独語 $(14 \%) 、$ 仏語 $(14 \%) 、$ 西語 $(6 \%) 、$ 伊語 $(3 \%)$ という順である。外国語の能力は、年齢と学習期間と強い関係があ り、15から 24 歳の年齢層および、そのなかでも高学歴者に有利な結果がみられ る。また、その必要性についても83\%が肯定している。このことは政治の優先 的な課題として $67 \%$ のが言語教育を推進するべきと考えていることと同傾向 である。こうしたなか、EUが揭げる母語以外の2つ以上の言語の習得については、 賛成が $50 \%$ 、反対 $44 \%$ という回答がでている。この質問に好意的な国は、賛成 意見の高い順にポーランド、ギリシャ、リトアニア、キプロス、ハンガリー、イ タリア、ラトビア、スペイン、エストニア、ベルギー (75\%から 60\%の国) であ る。他方、最も低い国はブルガリアで、27\%である。また、自己評価ではあるが、 2 以上の外国語(地域語、少数言語含む)を使いこなせるという人は $28 \%$ でる。 外国語を運用する状況というのは、海外旅行の $35 \%$ が最も高く、次に仕事 (海外

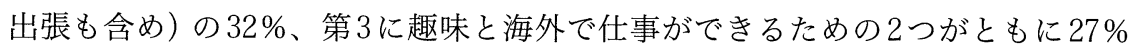
という結果となる。前回の 2001 年時点と大きく変化しているのは、仕事におけ る実用性が高まる一方、趣味や旅行目的は低い数值となっている点である。

また、第 1 外国語の能力の獲得あるいは向上を促した場所として、中等教育を

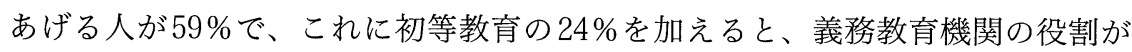
大きいことが判明する。第 1 外国語の始まりとしては、39\%が5歳以下を適齢と 考えている。そして $77 \%$ が、第1外国語として英語を考え、仏語(33\%)、独語 $(28 \%)$ を大きく引き離している。一方、生涯学習社会をスローガンとしているEUであ

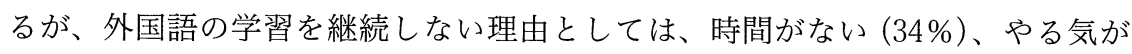


特集 教育と言語

ない $(30 \%)$ 、経費が高い $(22 \%)$ などが挙げられており、今後の課題も明らかに なっている。

次に、学校における外国語教育の現状について少し触れておくことにしよう。 Eurydiceの 2005 年の調査は、次のような言語の多様性を示す数值を提示してい る。15歳の生徒のうち $8 \%$ が家庭では学校の教授言語以外を使用するという。な お、これについては、北アイルランドの $0.7 \%$ からベルギー (フラマン語圈) の 34\%まで幅はある。その理由としては、EU外からの移民のケースも含まれてい ること、ベルギーのような国内における少数言語が存在することも無視できない ことが指摘される。

外国語教育の始まりがますます低年齢化し、小学校の低学年から始まることも 珍しくない（表 1)。また、義務教育期間における最低2つ以上の外国語教育の機 会の保障についてもほぼ、すべての加盟国で普及していることが明らかとなった。 しかし、中学校で2つ以上の外国語を学んでいるのは半数以下にすぎない。また、 英語、仏語、独語、西語、露語の5つが全外国語教育の95\%を占めている。無論、 これらの言語の分布は、地域によって異なる。たとえば露語は、バルト 3 国をは じめ、フィンランドやポーランド、ブルガリアなどで学習されている。英語につ いては、初等、中等ともに英語中心主義が顕著となっている。後期中等教育にお いても、外国語教育が義務か選択かに関係なく、約 $90 \%$ の生徒が学習している。

表 1 1984年と 2001 年の第 1 外国語教育の開始年齢

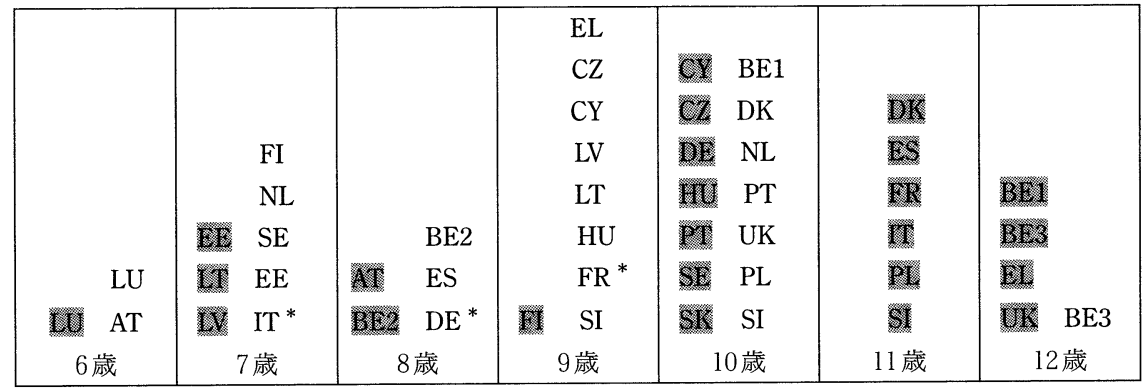

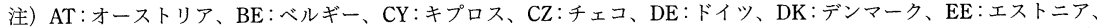
$\mathrm{EL}$ : ギリシャ、ES：スペイン、FI：フィンランド、FR：フランス、HU：ハンガリー、IT：イタリア、LT：リト アニア、LU：ルクセンブルク、LV：ラトビア、NL：オランダ、PL：ポーランド、PT : ポルトガル、 $\mathrm{SE}:$ スウェー デン、SI：スロベニア、SK：スロバキア、UK：連合王国 網掛けは1984年のデー夕。その右が2001年のデータ。

出典) Le Magazine, No22-2004, p.9. 
第2外国語としては独語と仏語が最も多い。独語の学習者は、おもに北欧と中、 東欧に多い。仏語は、南欧とくにラテン語系の諸国に人気がある。

義務教育期間における外国語の授業時間数は、総時間数の $9 \%$ （ポルトガル） から 34\%（ルクセンブルク）と開きがある。

外国語による教科の学習 (EMILE) のような教育を受けられる生徒の割合はま だ少ないが、各国の教育制度において近年確実に広まりつつある。

最後に、教員について若干述べると、初等教育では外国語の専任ではなく、 教科専任となるのは中学校以上である。また、外国語教員の初期養成 (Initial Teacher Training）期間は、4年ないし 5 年である。なお、外国での研修が推奨さ れている国はまだ稀である（ルクセンブルクとスコットランド）。

表 1 については、第 1 外国語の開始が低年齢化していること（6歳が4 から $8 \%$ 、 7 歳では 12 から 14\%へ、9歳までに $66 \%$ のどもが習い始める)、ルクセンブルク、 バルト 3 国など多言語社会の伝統国に、オーストリア、イタリア、ドイツ、スペ インなどが早期に外国語を教え始める国に加わったこと、そして10歳 (小学校) までに外国語を導入する国が増えていることが読み取れる ${ }^{(22)}$ 。

表2からは、1984年と較べて学習期間が長くなっていることが窺える。2001年

表 2 義務教育機関における第 1 外国語の学習年数 (1984年と 2001 年比較)

\begin{tabular}{|c|c|c|c|c|c|c|}
\hline UK & II & $\begin{array}{l}\text { BE1 } \\
\text { BE3 } \\
\text { EL } \\
\text { NL BE3 } \\
\text { SE UK }\end{array}$ & $\begin{array}{ll}\text { ES } & \\
\text { HR } & \text { PT } \\
\text { PI } & \mathrm{IT}^{*}\end{array}$ & $\begin{array}{l}\text { CY } \\
\text { C2 } \\
\text { PI } \\
\text { HU } \\
\text { BE1 } \\
\text { DL } \quad \text { DK } \\
\text { S1 } \quad \text { NL }\end{array}$ & $\begin{array}{ll} & \text { EL } \\
& \text { CY } \\
& \text { LT } \\
& \text { HU } \\
& \text { PL } \\
\text { SK } & \text { SK } \\
\text { DE } & \text { FR * }\end{array}$ & $\begin{array}{cl} & \text { BE2 } \\
& \text { ES } \\
\text { AT } & \text { CZ } \\
\text { BE2 } & \text { LV } \\
\text { DK } & \text { SI * }\end{array}$ \\
\hline 2年 & 3年 & 6年 & 7年 & 8年 & 9 年 & 10年 \\
\hline $\begin{array}{l}\mathrm{CE} \\
\mathrm{MT} \\
\mathrm{LV}: \mathrm{DE}^{*}\end{array}$ & $\begin{array}{l}\text { AT }^{*} \\
\text { DI } \\
\text { SV } \\
\text { EE } \\
\end{array}$ & LU LU & & & & \\
\hline 11年 & 12年 & 13年 & & & & \\
\hline
\end{tabular}

注）*印については、試験期間中で、今後広められる予定。マル夕については、デー夕不足のため揭載されていない。 UK については、スコットランドのみを対象としている。ベルギーについては、BE1(フランス語圈)、BE2 (ブリュッ セルとゲルマン語圈)、BE3 (フラマン語圈)を指す。

網掛けは 1984 年のデー夕。その右が 2001 年のデー夕。 
特集 教育と言語

では、9年以上が全体の $76 \%$ (1984 年には $36 \%)$ となっている。バルト 3 国につい ては、エストニアのみ 1 年長くなったのに対して、リトアニア、ラトビアは 9 年 と 10 年に短くなっているが、他方、最も消極的であったスコットランドおよび イタリアも、6 年と 7 年に延長している。また、同じ延長でもフィンランドのよ うに 8 年から 12 年間に大幅に延ばした国もある。その一方で、ベルギー（BE2、 BE3)、ポルトガル、スロバキア、ルクセンブルクのように変更のない国も存在 する。結局、表 1 にたように、第 1 外国語の学習期間が延長したため、小学校 からより早く学び始めることがEU諸国の傾向と言える。

\section{3 複数言語の習得に向けて}

さて、2002年 2 月の教育閣僚理事会が新たな施策を策定するよう要請したのを 受けて、欧州委員会は、翌年、3力年計画として外国語の学習と言語の多様性の 促進計画 : 2004-2006 年行動計画 (2003年7月 24 日付け) $)^{(23)}$ を発表し、8 2 億ユー ロを計上した。

その目的は、以下に示す通りである。

・母語以外に2つの言語を習得する。

・外国語の学習は、生涯にわたって行われる。

・多様性の促進という観点から、外国語には、地域語やマイノリティの言語も 含むものとする。

・学習時間および教員数・採用・養成において、外国語教育により積極的に投 資する。

・教授法の革新について、外国語以外の一般教科における外国語による教授法 (EMILE) や、情報技術を使用した教授法を促進する。

・ヨーロッパ諸国間における外国語能力の評価基準の統一をしていく。

・環境の改善のために、より多くの教育機関での学習を保障したり、さらに映 画などの字幕スーパーの作成を促す。

これらを実行に移すために、EUの教育・文化総局では、以下のような対策を 提言する。

・外国語教員の補助教員を奨励する。特に初等教育段階において。 
・初等教育の教材研究における国際的なプロジェクトに助成。

・初等教育における外国語による一般教科指導についての助成。

・教員抢よび一般市民向けに、インターネット上で外国語教育に関する情報サ イトの立ち上げ計画 (2006年予定)。

・教員に対して、既存のソクラテスやレオナルドダヴィンチ計画の教員交流プ ログラムの周知徹底 ${ }^{(24)}$ 。

・2006年にヨーロッパの外国語教員採用に関するシンポジウムの開催。

・ヨーロッパにおける地域語とマイノリティ言語の状況について出版助成 (2004 年)。

・2005年、2006年に外国語教育のコンピテンシーに関する指標作り。

・2004年から姉妹都市のプロジェクト助成に多言語主義のテーマを組み込む。

2004 年 3 月の欧州委員会では、量的な評価として、中等教育段階における外 国語（地域語、少数語含む）の学習言語数が、1990年代の平均 1.2 言語から 2000 年に 1.5 言語にしか増えていないことが不充分とされ㳊、質的評価においても、 2005 年時点で未だ適切な指標が策定されていないことが課題とされた ${ }^{(26)}$ 。そして 欧州委員会は、2006年7月 25 日の決議を受けて、欧州言語共通参照枠 $(\mathrm{CEF})$ を 活用した質的評価の着手に取りかかるとしている。こうした質的評価を行うため の指標については、2002年のバルセロナ欧州理事会で3つの戦略目標と13の目 標が採択され、2004年から 2006 年の 3 年間揭げられたが、新たな目標を定める 必要が生じたため、2007年に8つの分野に分けて 20 の指標(表3)が定められた ${ }^{(27)} 。$

表 3 教育訓練におけるリスボン戦略に向けた 20 の基本的な指標

\begin{tabular}{|ll|}
\hline 1) 就学前教育への参加度 & 11) 知識習得の多目的教室を核とした小学校の開発 \\
2) 特別なニーズへの配慮 & 12) 教師と実習 (研修) 担当教員の専門職開発 \\
3) 若者の離学状況 & 13) 教育訓練制度の層化 \\
4) 読解、数学、科学における知識 & 14) 高等教育修了者 \\
5) 外国語の知識 & 15) 高等教育の学生の流動性 \\
6) 情報技術の操作 & 16) 生涯学習への成人の参加度 \\
7) 市民性に関するコンピテンシー & 17) 成人のコンピテンシー \\
8) コンピテンシーの習得に関する学習 18$)$ 国民の教育水準 \\
9) 後期中等教育の就学率 & 19) 教育訓練への投資 \\
10) 学校経営 & 20) 教育訓練の収益率 \\
\hline
\end{tabular}


8つの分野とは、教育訓練の公平性の向上、教育訓練における効率性の促進、 生涯における教育訓練の学びの実現、若者のためのコンピテンシー、学校教育の 現代化、職業教育訓練の現代化(コペンハーゲン・プロセス)、高等教育の現代化(ボ ローニャ・プロセス)、エンプロイヤビリティである。

このような指標は、2006年12月18日付けの欧州議会と閣僚理事会の勧告によ る8つのコンピテンシーがもとになっている ${ }^{(28)}$ そここでは、8つのコンピテンシー として、母語によるコミュケーション、外国語によるコミュニケーション、数学 と科学・工学の基礎コンピテンシー、デジタルコンピテンシー、学び方を学習、 社会・市民性コンピテンシー、自発性および企業精神、文化的表現と感性が取り 上げられている。なお、ここで言及されている外国語のコミュニケーションとは、 聞く、話す、読む、書くという4つのレベルの習得と活用能力はもちろんのこと、 異なる文化への理解も含めた力を指している。

委員会は、こうした言語能力を高めるために教育訓練における 7 つ課題を提 示している ${ }^{(29)}$ 。第 1 に、各国は教育政策における言語の多様性を重要課題と位置 づけている。その場合、生徒には、すべての教育段階において言語教育の機会が 提供され、より多様な言語の選択が保障されるという点に注目したい。なお、こ こで言う言語とは、地域語や、移民子弟のホスト国の言語だけでなく、かれらの 出身言語も含み、その教育も含めた言語の多様性の保障が含意されている。第2 に教員養成の質の向上。第 3 に早期外国語教育の導入。そして第 4 に、外国語に よる他教科の学習、EMILEの活用である。第 5 に、非英語圈の高等教育におけ る英語による講義を、より多様な言語によって行うことである。第 6 には、高等 教育の多言語主義や異文化間性（interculturalité）に関する研究の拠点形成が待た れる。そして最後に、言語コンピテンシーの指標を早期に開発することが求めら れるとしている。

\section{おわりに}

近年導入された「リスボン戦略」以来、様々な言語教育の具体化、加速化、普 及に向けた取り組みがみられるが、23の公用語の教育についても、その言語能 力に関する基準が定まらないだけに、複数の言語を学ぶ機会の保障の実現には今 しばらく様子をみる必要がある。 
とはいえ、先述した欧州評議会による共通参照枠 (CEF) の普及とポートフォ リオ (ELP) の開発は、外国語教員の養成・研修、EMILEの開発などにおいて多 大な影響を与えている。EUのモットーである「多様性のなかの統一」を象徵する 言語の多様性は、1958年に、理事会がまず最初に定めた規則による加盟国の公 用語をすべて $\mathrm{EU}$ 諸機関の公用語とすることに始まり、2004年10月に調印した 欧州憲法条約の第 1-3条で、EUがその豊かな文化的かつ言語的多様性を尊重し、 欧州の文化遺産の保全と向上を確保することを謳っているように、今日まで一貫 している。こうした「違い」を尊重することこそが共存そして平和な社会を築く 基礎だと考えられ、また、異なった言語でコミュニケーションすることで文化摩 擦を和らげ、恒久的な文化的多元主義を目指すためには、複言語主義を促す言語 教育政策は欠かせないとされている ${ }^{(30)}$ 。

ただし、こうしたEUの政策にも限界がある。これまでにも多くの社会言語学 者 (31) することが求められるにもかかわらず、現構成国には求めていない。たとえば フランスのように「単一不可分な国」と憲法で定め、さらに1992年に憲法を改正 してまでその第2条に「共和国の言語はフランス語である」と明記した国もある。 このようにEUのスローガンである言語の多様性を否定する単一言語主義が強め られるという動きは他の加盟国にもみられる。さらに、「はじめに」でも述べた ようにヨーロッパ外（厳密には内外の線引きは難しい) からの移民の出身言語 (母 語、母国語の両方となるとさらに複雑である) を尊重し、教育や行政の場で複数 の言語の使用を認めるにはまだ時間を要するだろう。この意味においては、複言 語主義の実用面における調整は非常に難しい。

それでも、これまでみてきた EUの言語政策は、日本やアジアにおいて参考に なるだろう。今日のアジアで、日本語のプレゼンスは充分とは言えない。しか し、日本語を英語同様の国際語とすることや、国連公用語とすることが必ずしも 望まれるわけではない。EUおよび欧州評議会の研究から示唆が得られるとすれ ば、目指すべきは英語以外の複数の言語学習機会の保障であり、コミュニケーショ ン能力、特に論理的で自律的な討論能力の養成である。そして、欧州共通参照枠 (CEF)のような段階的な言語教育と、異文化を尊重するスキルの向上を併せた 教育も求められる。これらは、アジア圈という地域間交流の促進に貢献しょう。 
そのためには、まずはEU同様に、組織的、制度的な枠組みの調整が必要である。

\section{(参考文献)}

・「ことばと社会」編集委員会 (2004)『ヨーロッパの多言語主義はどこまできたか』三元社。

・正躱朝香 (2003)「多様性の中の統合』を目指す EU」『ヨーロッパ統合の国際関係論』 芦書房、303-333頁。

・倉智恒夫 (2003)「ヨーロッパ審議会と文化政策(1)」『川村学園女子大学研究紀要』第 14 巻第 2 号、161-180頁。

・杉谷眞佐子・高橋秀彰・伊東啓太郎 (2005)「EUにおける『多言語・多文化』主義」『外 国語教育研究』第 10 号、35-65頁。

・林良子 (2006)「EU の複言語主義」『近代』、35-48頁。

・松井嘉和 (2006)「EUと言語」EU と東アジア共同体』萌書房、111-126頁。

・園山大祐 (2006)「ヨーロッパ統合に関する教育政策の現状と展開—EU『リスボン戦略』 から一」『大分大学教育福祉科学部附属教育実践総合センター紀要』第 24 号、45-58頁。

・吉島茂・大橋理枝他＝訳・編 (2004)『外国語教育 II 外国語の学習、教授、評価のため のヨーロッパ共通参照枠』朝日出版社。

- Conseil de l'Europe (2000) Un cadre européen commun de référence pour les langues: Apprendre, enseigner, évaluer, Division des politiques linguistiques, Strasbourg.

- Commission Européenne (2006) Histoire de la coopération européenne dans le domaine de l' éducation et de la formation.

(注)

(1) ドイツ語、英語、デンマーク語、スペイン語、フィンランド語、フランス語、ギリシャ 語、イタリア語、オランダ語、ポルトガル語、スウェーデン語、エストニア語、ハン ガリー語、ラトビア語、リトアニア語、マルタ語、ポーランド語、スロバキア語、ス ロベニア語、チェコ語、アイルランド語、ブルガリア語、ルーマニア語の 23 言語であ る。ルクセンブルク語のように、国の公用語であっても EU の公用言語ではないもの もある。Euromosaic という調査によると、これら公用語以外に、約 60 の言語と、移民 による複数の言語が域内に存在するとされている。http://europa.eu.int/comm/education/ policies/languages/langmin/euromosaic/index_fr.html

(2) 1958 年、理事会がまず最初に定めた規則が、公用語に関するものである。理事会規 則第 1 号で、EU は、加盟国の公用語をすべて EU 諸機関の公用語とすると定めている。 そのため、加盟国が増えるたびに、理事会の決定を受けて公用語が追加されてきた。 しかし、11 カ国語体制における EU 全体の翻訳・通訳に関わる経費は、併せて EU 予 算の $1 \%$ 以下、EU 市民 1 人当たり年間2ユーロほどで、20力国語体制になっても、市 民 1 人当たりの支出は変わらないと言う (europe, spring 2004,p.22)。 
(3) COM (2005) 596final, p.3. なお、言語の多様性については、multilingue、plurilingue や、la diversité linguistique など様々な表現がある。ここでは、杉谷ほか (2005)「EUに おける『多言語・多文化』主義」35-65頁を参考にしている。つまり、「欧州評議会は、 『複数言語主義』(plurilingualism) という概念を打ち出している。それは、グローバル 社会で多様な言語が存在する事態を『多言語主義』(multilingualism) と称するのに対し、 個々人が一般教育機関等で複数の外国語を学習し、母語以外に複数の言語能力を習得 することを意味する」(38頁)。EUはこうした欧州評議会の言語の運用能力の差異にな らって、グローバル化が進む中で母語以外に複数 (2つ) の言語能力を求める。このよ うに、複 (数) 言語主義と多言語主義とは異なった概念であるとする。ただし、こうし た考え方の一貫性は、EUの刊行物には充分にみられるものではない。本稿では、で きる限り杉谷ほかのこうした議論を尊重しつつも、適宜言語に忠実に訳を当てている。 なお、杉谷らの「複数言語主義」という訳語も、「複言語主義」という訳語を当てた。 http://www.coe.int/t/dg4/linguistic/division_fr.asp?toPrint=yes\&

(4) http://www.europarl.europa.eu/charter/pdf/text-fr.pdf なお、その後「EU 基本権憲章」は、 「欧州憲法条約」に組み入れられた。2007年からは、基本権庁を創設し、EU 理事会事 務総長兼共通外交安全保障政策 (CFSP) 上級代表の人権問題担当個人代表ポストを新 設した。europe, winter 2006, pp.10-11, Règlement (CE) No168/2007 du Conseil du 15 février 2007, JOL53/1-14 du 22.2.2007.

(5) JO C364 du 18.12.2000, p.13.

（6）第 151 条第 1 項：欧州共同体は、構成国の国内的及び地域的多様性を尊重すると同時 に、共通の文化遺産を前面にだしながら、加盟各国の文化の繁栄のために寄与する。 第2項：欧州共同体による措置は構成国間の協力を助成しかつ必要に応じて以下の分 野においてそれらの活動を支持し補完することを目的とする。

第3 項 : 欧州共同体及び加盟国は、第三国及び文化分野において権限のある国際機関、 とりわけ欧州評議会との協力を促進する。

第4項:欧州共同体は、この条約の他の規定に基づく措置を執るに際して、文化的局面を、 特に文化的多様性を尊重し、促進するために考慮する。（正躱朝香 (2003)「『多様性の 中の統合』を目指す EU」『ヨーロッパ統合の国際関係論』芦書房、310-311頁より。下 線は引用者。)

(7) Décision No1934/2000/CE du Parlement européen et du conseil du 17 juillet 2000, JO L232 du 14.9.2000.また、毎年9月26日を「欧州言語の日」(European Day of Language) として いる。

(8) Conseil européenne de Barcelone, 15-16 mars 2002, Conclusions de la Présidence, partie I, 43,1, COM (2003) 449final, COM (1995) 590: Livre Blanc" Enseigner et apprendre”.

(9) Résolution 14 février 2002, JO C50 du 23.2.2002, 1/3-4.

(10) 本稿では、 langue, language の訳語として「外国語」としているが、原文では母語以 
外の言語すべて（公用語、地域語、少数言語など）を指していることもあることをお断 りしたい。必要に応じて地域語や少数言語という訳語を与えた。また、欧州外から入っ てくる移民の言語については「移民の言語」と言う。従って、少数言語には含まれない。 あるいは、言語教育というときに、母語（「国語」）教育もその範疇には含まれない。

(11) COM (2003) 449final, du 24.7.2003.

(12) Décision du Conseil “Education" du 14 février 2002. 拙稿 (2006)。

(13) Conclusion du Conseil du 24 mai 2005, JO C141 du 10.6.2005.

(14) 欧州評議会の言語政策については、倉智恒夫 (2003) や杉谷ほか (2005) に詳しい。

(15) http://www.coe.int/t/dg4/linguistic/Annex_FR.asp, Résolution (69) 2.

(16) http://www.coe.int/t/dg4/linguistic/default_fr.asp?より要約。

(17) CEF の翻訳は、吉島茂·大橋理枝他=訳・編(2004)『外国語教育 II 外国語の学習、教授、 評価のためのヨーロッパ共通参照枠』がある。

A 基礎段階の言語使用者 $\mathrm{B}$ 自律した言語使用者

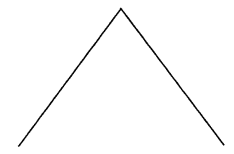

A1

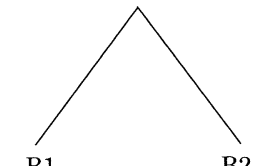

$\mathrm{B} 1$

B2
A2
C 熟達した言語使用者

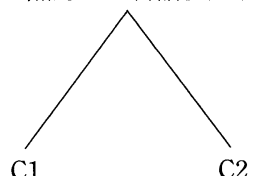

$\mathrm{C} 2$

A1: Breakthrough, A2: Waystage, B1: Vantage, B2: Threshold, C1: Mastery, C2: Effective Operational Proficiency

\section{図 CEF参照レベル}

\section{表 共通言語参照枠：全体的な尺度}

\begin{tabular}{|c|c|c|}
\hline \multirow{2}{*}{$\begin{array}{l}\text { 熟 } \\
\text { 達 } \\
\text { た } \\
\text { 言 } \\
\text { 語 } \\
\text { 使 } \\
\text { 者 }\end{array}$} & C 2 & $\begin{array}{l}\text { 聞いたり、読んだりしたほぼ全てのものを容易に理解することができる。 } \\
\text { いろいろな話し言葉や書き言葉から得た情報をまと、根拠も論点も一貫し } \\
\text { た方法で再構成できる。自然に、流暢かつ正確に自己表現ができ、非常に複 } \\
\text { 雑な状況でも細かい意味の違い、区別を表現できる。 }\end{array}$ \\
\hline & C l & 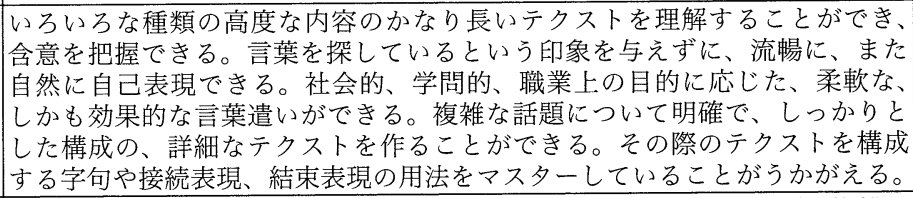 \\
\hline \multirow{2}{*}{$\begin{array}{l}\text { 夏 } \\
\text { 侓 } \\
\text { た } \\
\text { 言 } \\
\text { 語 } \\
\text { 便 } \\
\text { 者 }\end{array}$} & B 2 & $\begin{array}{l}\text { 自分の専門分野の技術的な議論も含めて、抽象的かつ具体的な話題の複雑な } \\
\text { テクストの主要な内容を理解できる。 } \\
\text { 互いに緊張しないで母語話者とやり取りができるくらい流暢かつ自然である。 } \\
\text { かなり広範な範囲の話題について、明確で詳細なテクスト作ることができ、 } \\
\text { さまざな言所や短所を示しながら自己の視点を説明できる。 }\end{array}$ \\
\hline & B l & 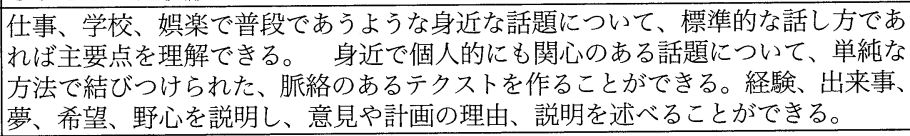 \\
\hline
\end{tabular}




\begin{tabular}{|c|c|c|}
\hline $\begin{array}{l}\text { 基 } \\
\text { 礎 } \\
\text { 段 } \\
\text { 皆 } \\
\text { の }\end{array}$ & A 2 & $\begin{array}{l}\text { ごく基本的な個人情報や家族情報、買い物、近所、仕事など、直接関係があ } \\
\text { る領域に関する、よく使われる文や表現が理解できる。 } \\
\text { 簡箪で日囲になら、身近で日常の事柄についての情報交換に応ずる } \\
\text { ことができる。 } \\
\text { 自分の背景や身の回りの状況や、直接的な必要性のある領域の事柄を簡単な } \\
\text { 言葉で説明できる。 }\end{array}$ \\
\hline $\begin{array}{l}\text { 言語 } \\
\text { 使 } \\
\text { 角 } \\
\text { 者 }\end{array}$ & A l & 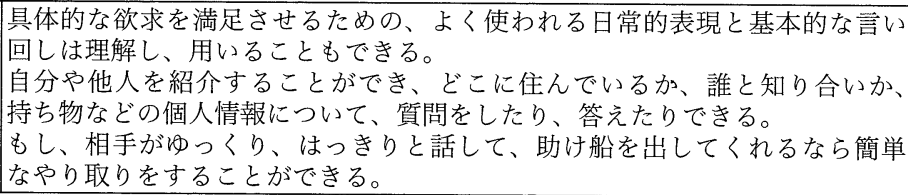 \\
\hline
\end{tabular}

出典) 吉島 ·大橋 (2004)、25頁、Conseil de l'Europe (2000): p.25.

(18) Résolution du Conseil du 31 mars 1995, JOC207 du 12.8.1995.

Commission Européenne (1995) Livre Blanc" Enseigner et apprendre”, pp.54-56. Eurydice (2006) L'enseignement d'une matière intégré à une langue étrangère (EMILE) à l'école en Europe.

(19) たとえば、ドイッについては、杉谷ほか、林 (2006) に詳しい。

(20) Euydice (2005) Chiffres clés de l'enseignement des langues à l'école en Europe, pp.90-92.

(21) Eurobaromètre (2006) Les Européens et leurs langues.

http://europa.eu.int/comm/public_opinion/archives/eb/ebs_147_fr.pdf

(22)こうした外国語教育の早期化については、1997年12月26日の Résolution sur l'enseignement précoce des langues (JO C1 du 3.1.1998) 以来の方針結果でもある。

(23) http://europa.eu.int/comm/education/doc/official/keydoc/actlang_lang_fr.pdf

(24) ちなみに、2000年から 2002 年におけるソクラテス計画では、1601件の言語プロジェ クトを助成し、 58500 人の生徒と 6500 人の教員、 2440 人の補助教員、16563人の外国 語教員の現職研修に当てられたことになる。エラスムス事業における低頻度使用およ び教授言語の語学研修 (BELMR) として 3632 人の学生が派遣されている。同時期のレ オナルドダヴィンチ計画においては、750件の外国語教員の外国研修、専門職研修と いう目的で56件の教材研究のプロジェクトを助成している。Le Magazine, No22-2004, pp.11, 13, 15 .

BELMR (Bureau européen des langues moins répondues) とは、1982年に設立され、ブ リュッセルに本部がある。ここで言う低頻度使用および教授言語とは、23の公用語以 外の使用言語に限らず、たとえば、ベルギーにおけるドイツ語圏のように、その地域 では少数派の言語である場合にも該当する。従って、上述した 3632 人の学生のなかに は、ベルギーにおけるドイツ語話者などのようなケースも含まれる。

(25) Conseil de l'Union Européenne, doc.6905/04, EDUC43 du 3.3.2004.

(26) COM (2005) 356final, du 1.8.2005.

(27) COM (2007) 61final, du 21.2.2007. 


\section{特集 教育と言語}

(28) Recommandation du Parlement Européen et du Conseil du 18 décembre 2006 sur les compétences clés pour l' éducation et formation tout au long de la vie (2006/962/CE) JO L394/10-18.

(29) COM (2005) 596final du 22.11.2005.

(30) europe, summer 2005, pp.2-6.

(31) その代表的なもののみ示す。三浦信孝(2001)「共和国の言語、フランスの諸言語」『普 遍性か差異か』藤原書店ほか多数。サレム・シャケール (2000)「欧州地域語少数言語 憲章は憲法違反か」『言語帝国主義』藤原書店。憲法学の視点からは、糠塚康江 (2003)「『 にして不可分の共和国』と多言語主義」『欧州統合とフランスの憲法の変容』有斐閣が ある。 